\title{
GARANTIA DO PROCESSO SEM DILAÇÕES INDEVIDAS: RESPONSABILIDADE DO ESTADO PELA INTEMPESTIVIDADE DA PRESTAÇÃO JURISDICIONAL
}

\author{
José Rogério Cruz e Tucci \\ Professor Associado do Departamento de Direito Processual da \\ Faculdade de Direito da Universidade de São Paulo e Presidente \\ da Comissão de Pós-Graduação da Faculdade de Direito da \\ USP. Assessor ad hoc da FAPESP. Ex-Presidente da AASP. \\ Advogado em São Paulo.
}

Resumo:

A tutela jurisdicional eletiva e tempestiva, seguida da determinação dogmática da dicção prazo razoável e do critério de razoabilidade dela, além do tempo da investigação criminal e da prisão provisória, a recepção da garantia pelo Direito brasileiro, o devido processo legal e seus corolários (o lempo justo) são os temas abordados pelo autor neste artigo.

Abstract:

The effective and in time jurisdictional tutelage, added to the dogmatic determination of the reasonable time's diction and its reasonability criterious, in addition to the time of criminal investigation and the provisory prison, the guarantee's reception in Brazilian Law, the due process of law and its corollaries (the just time) are the themes approached by the author on this article.

Unitermos: tutela jurisdicional; dicção prazo razoável; devido processo legal; ternpo juslo.

1. Efetividade e tempestividade da tutela jurisdicional

Relegando a um plano secundário as construções de cunho teórico, que tanta relevância ostentaram até há bem pouco tempo, os processualistas passaram a preocupar-se com um valor fundamental, ínsito à tutela dos direitos, qual seja a imprescindibilidade da efetividade do processo, enquanto instrumento de realização da Justiça.

Como adverte, a propósito, Barbosa Moreira, "toma-se consciência cada vez mais clara da função instrumental do processo e da necessidade de faẑे-lo desempenhar de maneira efetiva o papel que lhe toca".

1. Tendências contemporâneas do direito processual civil, in Temos de direior processual, $3^{3}$ s., Sĩo Paulo, Saraiva, 1984, p). 3. V., ainda, Barbosa Moreira, Notas sobre o problema da "eletividade" do processo, in Ajuris, 29( 1983):77 ss.; e o volume L'effectivité des décisions de justice (journées finaņaises), Travaux de l'Association Henri Capitant, t. 36, Paris, Economica, 1987. 
É, pois, preciso oferecer ao processo mecanismos que permitam o cumprimento de toda a sua missão institucional, evitando-se, com isso, que seja considerado "fonte perene de decep̧̧ões" 2

Assim, incumbe ao ordenamento processual atender, do modo mais completo e eficiente possível, ao pleito daquele que exerceu o seu direito à jurisdição, bem como daquele que resistiu, apresentando defesa.

É que, no âmbito do processo civil de conhecimento, a tutela jurisdicional, representada pela sentença de mérito, pode ou não acolher a pretensão deduzida, beneficiando, por via de conseqüência, tanto o autor quanto o réu. Tudo ficia na dependência de quem obtenha êxito, amparado que esteja pelo direito material. ${ }^{3}$

Para isso, é de suma relevância que o processo civil disponha de mecanismos aptos a realizar a função institucional que the toca, qual seja a de assegurar ao jurisdicionado que tenha razão praticamente tudo aquilo e exalamente aquilo que, porventura, tenha direito de receber: ${ }^{4}$

$\mathrm{Na}$ verdade, as legislações processuais modernas "devem construir procedimentos que tutelem de forma efetiva, adequada e tempestiva os direitos. $O$ ideal é que existam tutelas que, atuando internamente no procedimento, pernitam uma racional distribuição do tempo do processo" 5

Assim, ao lado da efetividade do resultado que deve conotá-la, imperioso é também que a decisão seja tempestiva.

O pronunciamento judicial que cumpre com sua nobre missão de compor uma controvérsia intersubjetiva ou um conflito de alta relevância social (na esfera penal), no momento oportuno, proporciona às partes, aos interessados e aos operadores do direito grande satisfação. Mesmo aquele que sai derrotado não deve lamentar-se da pronta resposta do Judiciário, uma vez que, sob o prisma psicológico, o possível e natural inconformismo é, sem dúvida, mais tênue quando a luta processual não se prolonga durante muito tempo.

É inegável, por outro lado, que, quanto mais distante da ocasião tecnicamente propícia for proferida a sentença, a respectiva eficácia será proporcionalmente mais fraca e ilusória. De tal sorte, "un julgamento tardio irá perdendo progressivamente seu sentido reparador, na medida em que se postergue o

2. Dinamarco, A instrumentalidade do processas, $5^{\text {a }}$ ed., São Paulo, Malheiros, 1996, pp. 271.

3. V., nesse sentido, Flávio Luiz Yarshell, Tutela jurisdicional e tipicidade, tese de doutoramento (USP), São Paulo, 1997, pp. 12.

4. Andrea Proto Pisani, Appunti sulla tutela di condanna, in Studi in onore di Enrico Tullio Liebmam, v. 3, Milano, Giuffrè, 1979, pp. 1.738-9, valendo-se, como é notório, de clássica doutrinação de Chiovenda quanto ao escopo do processo.

5. Cf. Marinoni, Tutela antecipatória, julgamento antecipado e execução imediata da sentença, São Paulo, Ed. RT, 1997, pp. 20. A efetividade das decisōes judiciais, conforme lição de Carnelutti, poderá ser assegurada pelas medidas cautelares, que constituem antídoto contra a demora do processo (Diritto e processo, Napoli, Morano, 1958, pp. 35.5-6). V., nesse sentido, Dinamarco, A instrumentalidade do processo, cit., p|). 302. 
momento do reconhecimento judicial dos direitos; e, transcorrido o tempo razoável para resolver a causa, qualquer solução será, de modo inexorável, injusta, por maior que seja o mérito científico do conteúdo da decisão" "

Parece mesmo fora de questão que a oportunidade do provimento " $a$ tempestività a que se referem os italianos, como resultado do equilíbrio entre os tempos de progresso $e$ tempos de espera (tempi di sviluppo e tempi di attesa) - constitui um dos primordiais elementos para determinar o grau de eficiência dos tribunais" 7

Em suma, o resultado de um processo "não apenas deve outorgar uma satisfação juridica às partes, como também, para que essa resposta seja a mais plena possível, a decisão final deve ser pronunciada em um lapso de tempo compatível com a natureza do objeto litigioso, visto que - caso contrário se tornaria utópica a tutela jurisdicional de qualquer direito. Como já se afirmou, com muita razão, para que a Justiça seja injusta não faz falta que contenha equívoco, basta que não julgue quando deve julgar"s!

E isso, por certo, tanto quanto no trato dos direitos de natureza indisponíve] em sede extrapenal, na esfera criminal a idéia de tempestividade da decisão engloba outros valores e outras exigências, "de sorte a tornar-se inafastável a inclusão, na concepção do devido processo penal, do direito do indiciado ou acusado de obter pronunciamento judicial. que "ponga término del modo más rápido posible a la situación de incertidumbre y de inegable restricción de la libertad que comporta el enjuiciamiento penal" "'

Não se pode olvidar, nesse particular, a existência de dois postulados que, em princípio, são opostos: o da segurança jurídica, exigindo, como já salientado, um lapso temporal razoável para a tramitação do processo ("tempo fisiológico"), e o da efetividade deste, reclamando que o momento da decisão final não se procrastine mais do que o necessário ("tempo patológico"). Obtendo-se um equilíbrio destes dois regramentos - segurança/celeridade - emergirão as melhores condições para garantir a Justiça no caso concreto, sem que, assim, haja diminuição no grau de efetividade da tutela jurisdicional. ${ }^{10}$

2. Determinação dogmática da diç̧ão prazo razoável.

Impende reconhecer que a garantia da ampla defesa e o correspectivo

6. Cf. Rafael Bielsa e Eduardo Graña, El tiempo y el proceso, in Revista del Colegio de Abogados de La Plata, La Plata, 55(1994):189.

7. Cf. Bielsa e Graña, El tiempo y el proceso, cit., pp. 189, com lastro em doutrinação de Giuseppe Tarzia, que se referiu a tal dicotomia no artigo intitulado "Quali riforme pela la giustizia civile?", in Giurisprudenza ifaliana, 1987, pt. IV.

8. Cf., ainda, Bielsa e Graña, El tiempo y el proceso, cit., pp. 190.

9. Lauria Tucci, Direitos e garantias individuais no processo penal brasileiro, São Paulo, Saraiva, 1993. pp. 290, com arrino em Alejandro D. Carrió, Garantias constinucionales en el proceso penal, Buenos Aires, Hammurabi, 1984, pp. 132.

10. V., a respeito, José Luis Albacar Lopez, La durata e il costo del processo nell'ordinamento spagnolo, 
direito à tempestividade da tutela jurisdicional são valores constitucionalmente assegurados. É até curial que o direito de acesso à ordem jurídica justa, consagrado no art. $5^{\circ}, \mathrm{XXXV}$, da Constituição Federal, não exprima apenas que todos podem ir a juízo, mas, também, que todos têm direito à adequada tutela jurisdicional, ou melhor, "à tutela jurisdicional efetiva, adequada e tempestiva" "

Destaca, nesse sentido, Teresa Sapiro Anselmo Vaz ${ }^{12}$ que o direito à jurisdição "é indissociável do direito a uma tutela judicial efectiva que, por sua vez, pressupõe o direito a obter uma decisão em prazos razoáveis, sem dilações indevidas. Ou seja, a tutela judicial efectiva implica uma decisão num lapso de tempo razoável, o qual há-de ser proporcional e adequado à complexidade do processo"

Na Europa Ocidental e na América do Norte, a despeito da alarmante lentidão verificada na Justiça de vários países, o direito a um processo sem dilações indevidas vem consagrado em inúmeros textos legislativos, dos quais derivou fecunda elaboração doutrinária e jurisprudencial.

O art. $6^{\circ} 1$, da Convenção Européia para Salvaguarda dos Direitos do Homem e das Liberdades Fundamentais, subscrita em Roma no dia 4 de novembro de 1950, prescreve que: "Toda pessoa tem direito a que sua causa seja examinada eqüitativa e publicamente num prazo razoável, por um tribunal independente e imparcial instituído por lei, que decidirá sobre seus direitos e obrigações civis ou sobre o fundamento de qualquer acusação em matéria penal contra ela dirigida" 13

Foi, sem dúvida, a partir da cdição desse diploma legal supranacional, que o direito ao processo sen dilações indevidas passou a ser concebido como um direito subjetivo constitucional, de caráter autônomo, de todos os membros da coletividade (incluídas as pessoas jurídicas) à tutela jurisdicional dentro de um prazo razoável, decorrente da proibição do non liquet, vale dizer, do dever que têm os agentes do Poder Judiciário de julgar as causas com estrita observância das normas de Direito Positivo.

Efetivou-se, outrossim, ao longo do tempo, a necessária exegese da abrangência do dispositivo em apreço, tendo-se, unanimemente, como dilações indevidas, "os atrasos ou delongas que se produzem no processo por inobservância dos prazos estabelecidos, por injustificados prolongamentos das etapas mortas que separam a realização de um ato processual de outro, sem subordinação a um lapso

in Rivista trimestrale di diritto e procedura civile, tr. it. Gigliola Funaro, 1983, pp. J. 102; Les temps dans: la procédlure, obra coletiva dirigida por Jean-Marie Coulon e Marie-Anne Frison-Roche, Paris, Dalloz, 1996; Ovídio A. Baptista da Silva, Curso de processo civil, v. I, Porto Alegre, Sérgio Fabris, 1987, pp. 158.

11. Cf., nesse sentido, Marinoni, Tutela antecipatória, julgamemo antecipado e execugão imediata da sentença, cit., pp. 20.

12. Novas tendências do processo civil no âmbito do processo declarativo comum (alguns aspectos), in Revista da Ordem dos Advogados, Lisboa, 55(1995): 851.

13. V., especificamente, Patrick Grzybek, Prozessuale Grundreche im Europäischen Gemeinshaftsrecht, Baden-Baden, Nomos, 1993, pp. 75-6. 
temporal previamente fixado, e, sempre, sem que aludidas dilações dependam da vontade das partes on de seus mandatários" 14

Todavia, torna-se impossível fixar a priori uma regra especílica, determinante das violações à garantia da tutela jurisdicional dentro de um prazo razocivel.

E, por isso, consoante posicionamento jurisprudencial da Corte Européia dos Direitos do Homem, três critérios, segundo as circunstâncias de cada caso concreto, devem ser levados em consideração para ser apreciado o tempo razoável de duração de um determinado processo. Por via de conseqüência, somente será possível verificar a ocorrência de uma indevida dilação processual a partir da análise: $a$ ) da complexidade do assunto; $b$ ) do comportamento dos litigantes e de seus procuradores ou da acusação e da defesa no processo penal; e $c$ ) da atuação do órgão jurisdicional. ${ }^{15}$

Como observa, a esse respeito, Jean-Pierre Marguénaud, "l'appréciation du caractère raisonable de la durée de la procédure, elle se réalise au cas par cas eu égard aux critères consacrés par la jurisprudence de la Cour, notamment la complexité de l'affaire, le comportement des requérants et celui des antorités compétentes" i6

O reconhecimento desses critérios traz como imediata conseqüência a visualização das dilações indevidas como um conceito indeterminado e aberto, que impede de considerá-las como o simples desprezo aos prazos processuais préfixados. ${ }^{17}$

Assim, é evidente que se uma determinada questão envolve, por exemplo, a apuração de crimes de natureza fiscal ou econômica, a prova pericial a ser produzida poderá demandar muitas diligências que justificarão duração bem mais prolongada da fase instrutória.

O Tribunal Europeu exige da parte queixosa "diligência normal" no desenrolar do processo, "não lhe sendo imputavel a demora decorrente do exercício de direitos ou poderes processuais, como o de recorrer ou de suscitar incidentes..." Ix

14. Cf. José Antonio Tomé Garcia, Protección procesal de los derechos humanos ante los lribunales ordinarios, Madrid, Montecorvo, 1987, pp. 119; com lastro em José Almagro Nosete. V., ainda, Vicente Gimeno Sendra, Constitución y proceso, Madrid, Tecnos, 1988, pp. 144 ss.; Cruz e Tucci, Garantia da prestação jurisdicional seın dilações indevidas como corolário do devido processo legal, in Devido processo legal e tutela jurisdicional, São Paulo, Ed. RT, 1993, pp. 104.

15. V., a propósito, Gimeno Sendra, Constitución y proceso, cit., pp. 144 s.; José M. Bandres SanchezCruzat, El tribunal europeu de los derechos del hombre, Barcelona, Bosch, 1983, pp. 91. Consulte-se, ainda, a pesquisa intitulada "Justice for all - reducing costs and delay in civil litigation", in Report of a lask force, Washington-DC, The Brookings Institution, 1989, pp. 11 s..

16. La Cont européenne des droits de l'homme, Paris, Dalloz, 1997, pp. 94.

17. Cl. Mercedes García Arán, La prevaricación judicial, Madrid, Tecnos, 1990, pp. I.56. V., ainda, Héctor Faundez Ledesma, El derecho a un juicio justo, in Revista de la faculdad de Ciencias Juridicas y' Políicas, Universidad Central de Venezuela, 80(1991):158.

18. Cf. José Lebre de Freitas, Introduşão ao processo civil - conceito e princípios gerais à luz do Coidigo revisto, Coimbra, Coimbra Ed., 1996, pp. 112, nt. 8. 
Por outro lado, não poderão ser taxadas de "indevidas" as dilações proporcionadas pela atuação dolosa da defesa, que, em algumas ocasiões, dá azo a incidentes processuais totalmente impertinentes e irrelevantes. ${ }^{19}$

E, ademais, é necessário que a demora, para ser reputada realmente inaceitável, decorra da inércia, pura e simples, do órgão jurisdicional encarregado de dirigir as diversas etapas do processo. É claro que a pletora de causas, o excesso de trabalho, não pode ser considerado, neste particular, justificativa plausível para a lentidão da tutela jurisdicional.

$\mathrm{Na}$ aferição que é realizada pelo Tribunal de Estrassburgo têm também muito peso a natureza e algumas características do processo em que teria ocorrido indevida demora, como, por exemplo, as causas penais (sobretudo quando detido o réu), ou, ainda, a qualidade do demandante nas questões cíveis de cunho indenizatório, e. $g$., se deficiente físico, se portador de aids... ${ }^{20}$

Constituindo sério precedente, a Corte Européia dos Direitos do Homem, no julgamento ocorrido em 25 de junho de 1987, condenou o Estado italiano a indenizal uma litigante nos tribunais daquele país pelo dano moral "derivante do estado de prolongada ansiedade pelo êxito da demanda"

Eis a íntegra do acórdão: ${ }^{21}$

"Direitos políticos e civis - Itália - Duração dos procedimentos judiciais - Limites razoáveis - Caso concreto - Violação da Convenção - Ressarcimento do dano Critérios de determinação (Convenção Européia para a Salvaguarda dos Direitos do Homem e das Liberdades Fundanentais: arts. $6^{\circ}$ e 50)

- Excede os termos razoáveis de duração, prescritos pelo art. $6^{\circ} 1$, da Convenção Européia para a Salvaguarda dos Direitos do Homem e das Liberdades Fundamentais, o processo não particularmente complexo, tanto em matéria de fato, quanto em matéria de direito, e que ainda não foi concluído depois de dez anos e quatro meses de seu início.

- O motivo no sentido de que o processo italiano é inspirado pelo princípio dispositivo não se põe em contraste com a Convenção, e também não dispensa o juiz do dever de atender aos limites de duração prescritos no art. $6^{\circ}$. I, da Convenção Européia para a Salvaguarda dos Direitos do Homem e das Liberdades Fundamentais.

- Com a finalidade de valorar a contribuição da parte à causa dos atrasos que determinaram a excessiva duração do processo, nem todos aqueles devidos a atos do defensor são imputados à parte.

19. Cf. Gimeno Sendra, Moreno Catena e Cortés Domínguez, Derecho procesal proceso penal, Valencia, Tirant Lo Blanch, 1993, pp. 94-5. O art. 424, par. ún., de nosso CPP, prevê a possibilidade de desaforamento do julgamento pelo júri quando ainda não realizado "no periodo de I (um) (mo, comlado do recebimento do libelo, desde que para a demora não haja concorrido o réu ou a defesa"

20. Cf.. Jean-Pierre Marguénaud, La Cour européenne des droits de l'homme, cit., pp. 95.

21. Publicado no periódico Il foro italiano, parte IV-28, 1987, pp. 385-90; e traduzido em nosso artigo Dano moral decorrente da excessiva duração do processo, in Temas polêmicos de processo civil, São Paulo, Saraiva, 1990, pp. 96-103. 
- O Estado italiano é responsável pelas delongas dos trabalhos periciais, como conseqüência da falta de exercício dos poderes de que o juiz dispõe, inclusive no tocante à inobservância dos prazos por ele deferidos.

- O Estado italiano é obrigado a pagar à requerente, em face da excessiva duração do processo no qual é ela autora, a soma de oito milhões de liras, determinada eqüitativamente ao ressarcimento, seja do dano material advindo das despesas efetuadas e das perdas sofridas, seja do dano moral derivante do estado de prolongada ansiedade pelo êxito da demanda.

De direito - 'Sobre a alegada violação ao art. $6^{\circ}, 1$ :

21. De acordo com a requerente, o exame de sua demanda durou muito mais do que um tempo razoável, previsto no art. $6^{\circ}, 1$, da Convenção, que dispõe o seguinte: 'Toda pessoa tem direito a que sua causa seja examinada eqüitativa e publicamente num prazo razoável, por um tribunal independente e inparcial instituído por lei, que decidirá sobre seus direitos e obrigações civis ou sobre o fundamento de qualquer acusação em matéria penal contra ela dirigida'

O Estado demandado combate essa tese, que foi acatada pela Comissão de instrução.

\section{A. Periodo a considerar}

22. O período a considerar é incontroverso. Ele teve seu início em 10 de janeiro, data na qual os réus deveriam ter comparecido, uma vez que a legislação italiana permite ao autor indicar a data da audiência prévia. Por outro lado, ainda não se findou, porquanto o processo continua pendente.

Trata-se então de um lapso de tempo que já ultrapassa dez anos e quatro meses (10-1-77 a 19-5-87).

\section{B. Razoabilidade de duração de um processo}

23. O tempo razoável de duração de um processo deve ser apreciado em consonância com as circunstâncias da causa e com o auxílio de critérios consagrados pela jurisprudência da Corte (v., especialmente, o aresto Zinmermann e Steiner, de 13 de julho de 1983, série A, n. 66, pp. 11, \$24; Foro it., Repp. 1985, verbete Diritti politici e civili, n. 25).

24. O Estado demandado ressalta que na Itália o processo civil se encontra regido pelo 'princípio dispositivo', que consiste em conferir às partes poderes de iniciativa e de impulso. Cita, a título de exemplo, os arts. 99, 115 e 306 do CPC.

$\mathrm{O}$ advogado da requerente contesta essa argumentação. Segundo cle, somente incumbe à parte dar início à ação civil, não a condução de todo o processo, como prevêem os arts. 175 do CPC e 81 das disposições de aplicação do mesmo.

25. A Convenção, por certo, não impede os Estados signatários de fundar o processo civil no aludido princípio, todavia, não se dispensa ao juiz assegurar o respeito às exigências do art. $6^{\circ}$ no que se refere a tempo razoável (v., mutatis mutandis, o aresto Guincho, de 10 de julho de 1984, série A, n. 81, pp. 14, \$ 32; Foro it., 1986, IV, 60). 
De resto, nos termos do art. 175 do CPC, o juiz instrutor "exerce todos os poderes destinados ao mais rápido e leal desenvolvimento do procedimento

Complexidade do caso

26. A Corte entende, em consonância com as razões da requerente e com a conclusão da Comissão de instrução, que o caso não era complexo nem de fato nem de direito.

\section{Comportamento da requerente}

27. A Comissão de instrução atribui à requerente, Sra. capuano, um atraso de aproximadamente I ano; mostrando, de resto, uma 'diligência normal'

A requerente considera que não lhe poderia imputar nem o atraso decorrente da destituição de seu procurador; nem aquele, de aproximadamente quatro meses ( $1^{\circ}-6$ a 20-9-77), que foi necessário para retomar o processo; e tampouco o período de 20-09 a 29-11-77.

Para o Estado demandado, ao contrário, o comportamento da requerente constitui a causa, não apenas de mencionados atrasos, como também de muitos outros: especialmente dos adiamentos requeridos por seu procurador para produção de provas, e memoriais, cuja apresentação foi requerida por ambas as partes, ou somente pelos réus, sem que a requerente se opusesse.

28. A Corte adota em larga medida a tese da Comissão de instrução. Se não se afigura possível considerar a requerente como responsável pela delonga devida à destituição de seu advogado, outros atrasos do procedimento podem ser a cla atribuídos.

Seu novo advogado, por exemplo, tendo sido constituído em 13-4-77, aguardou mais dois meses para requerer o prosseguimento do feilo. Ele requereu, em seguida, em 20-09, a suspensão do processo para produzir prova; ao depois, em 29-11, uma perícia, não formulando, contudo, os respectivos quesitos. Resultou daí uma demora aproximada de 4 meses.

No entanto, diferentemente da Comissão, a Corte não pode atribuir à requerente os adiamentos de 9-10-79 e 19-05-81: o primeiro foi requerido pelo procurador de um dos réus, e a audiência não pode ser realizada pelas razões acima apontadas.

As críticas dirigidas pelo demandado à requerente, no tocante a diversos outros atrasos, não se delineiam pertinentes, em decorrência dos adiamentos pleiteados pelos réus.

Em suma, a requerente concorreu até uın certo momento para a delonga do processo (v. aresto Pretto e outros, de 8-12-83, série A, n. 7I, pp. 15, \$ 34; Foro it., 1984, IV, 265).

\section{Comportamento das autoridades judiciárias}

29. Segundo a Comissão, o comportamento das autoridades judiciárias determinou várias procrastinações. 
Ao ver da Corte, afigura-se necessário estabelecer a distinção entre o procedimento de primeiro grau (10-12-77 a 20-7-83) e o procedimento recursal (21-783 a 19-05-87).

\section{Procedimento de primeiro grau}

30. Perante o tribunal de Lagonegro o processo durou seis anos, oilo meses e dez dias.

Tendo-se em vista a ausência de complexidade do caso, tal lapso temporal apresenta-se, de logo, contrário à observância da razoabilidade de tempo. Tal fato, portanto, merece delalhado exame.

A Corte verilica que ele se deveu em boa parte dois anos, onze meses e três dias - à espera dos dois laudos periciais.

De acordo com o Estado demandado, a responsabilidade não é do órgão jurisdicional: sem dúvida, cada um dos laudos foi apresentado a destempo, mas os poderes do juiz, contra a atividade de um perito que não atua com a diligência reclamada, limitam-se a uma singela multa.

A Corte robora tal conclusão. Na espécie, o perito atuava no âmbito de um procedimento judiciário subordinado a controle do magistrado, a cuem incumbe a instrução e rápida condução do processo.

Quanto à sanção que ele podia impor ao perito, deve ser lembrado que, ao ratificar a Convenção, a Itália assumiu a obrigação de aparelhar a sua organização judiciária de modo a permitir o cumprimento das condições do art. $6^{\circ} 1$, especialmente no que se refere a tempo razoável (aresto Guincho, cit., série A, n. 81, pp. 16, § 38).

31. Consoante, ainda, o Estado demandado, a requerente deveria exigir a substituição do perito.

Sobre esse ponto, a Corte se prende à conclusão da Comissão de instrução: nada autoriza a presumir que aquela substituição teria evitado a demora das perícias.

De outra parte, a requerente não estava obrigada a requerer ao juiz (v., mutatis mutandis, o aresto Guincho, cit., série A, n. 81, pp. 15, \$34), e a decisão, ademais, independia de requerimento, podendo ser determinada de olício (art. 196 do $\mathrm{CPC})$.

O demandado também acusa a requerente pelo fato de não ter comunicado, ao Ministério Público, a atitude do perito, por lorça do disposto no art. 328 do CPP.

Apesar de tudo, longe de abreviar o procedimento, tal iniciativa te-lo-ia, provavelmente, prolongado.

32. Considerando os limites dos poderes das partes, a responsabilidade pelo atraso decorrente das perícias deve, à evidência, ser imputada ao Estado.

É certo que o juiz fixou um prazo de 60 dias para a realização de cada uma das perícias; além disso, determinou por três vezes a apresentação da segunda delas. Todavia, somente foi oferecida após aquele interregno.

Ora, teria sido possível substituir o perito no lapso de 9 meses, nos quais 
o processo restou paralisado. De sorte que nenhum controle foi exercido acerca do desenvolvimento do trabalho pericial.

33. A propósito dos períodos que vão da apresentação da primeira perícia até a decisão de fazer-se outra (5-1-79 a $1^{\circ}$-4-80) e da apresentação da segunda até o julgamento (25-3-82 a 20-7-83), a Corte constata que os adiamentos foram requeridos pelos réus ou ordenados de ofício pelo juiz, à exceção de dois, ensejados pela requerente.

A Corte observa, por outro lado, que, por duas vezes, o procurador da Autora requereu ao tribunal que proferisse decisão (4-5 e 29-6-82).

\section{Procedimento recursal}

34. Quanto ao procedimento em grau de recurso, iniciou-se ele há quase quatro anos e, ainda, não obteve decisão alguma sobre o mérito.

Este lapso de tempo que se afigura de per se excessivo acresce a uma fase anterior que já havia durado em demasia.

Portanto, a Corte não entende necessário analisar as diversas vicissitudes e notadamente pronunciar-se sobre a conversão do julgamento em diligência determinada pelo Tribunal de Potenza.

\section{Conclusão}

35. Em resumo, a requerente, não obteve o exame de sua demanda em um tempo razoável, mesmo se possível lhe imputar a responsabilidade por qualquer dos atrasos verificados.

Houve, destarte, violação à regra do art. $6^{\circ} .1$.

\section{Sobre a aplicação do art. 50}

36. Dispõe o art. 50 da Convenção: 'Se a decisão da Corte declara que um julgamento proferido ou uma medida ordenada por uma autoridade judiciaria, ou qualquer outra autoridade de uma das partes contratantes, encontra-se inteira ou parcialmente em oposição às obrigações estatuidas pela Convenção, e se o direito interno de tal parte não permite reparação integral dos danos oriundos do julgamento ou da medida, a Corte concede, se caso, ao demandante lesado, uma satisfação equânime'.

Em suas razões, de 28-5-86, a requerente reclamou uma indenização equivalente a cem milhões de liras, sob vários títulos, entre os quais não se incluíam as despesas efetuadas neste processo.

A partir das audiências, seu procuraclor também deduziu, perante a Corte, a pretensão da sua constituinte de ser reembolsada, não-somente das custas despendidas nos tribunais italianos, mas, ainda, dos prejuízos decorrentes da deterioração do imóvel litigioso e da tensão física e psicológica em virtude da demora quase onze anos - do processo.

O requerido insiste na desproporção existente entre a quantia aqui demandada e o valor do bem objeto do litígio. 
Aduz, outrossim, que, alguns dos danos alegados, não estão compreendidos pela regra do art. 50, e que outros, não especificados, não resultam das falhas denunciadas.

A Comissão entende que a requerente tem direito a uma indenizaç̧̃̃o por dano moral. No que concerne ao prejuízo material, ela deixa à Corte a incumbência de lixar o montante.

37. No entender da Corte, o único parâmetro para a concessão de uma satisfação equânime pelo dano material consiste na superação do tempo razocivel, previsto no art. $6^{\circ}, 1$ (v., especialmente, o aresto Lechner e Hess, de 23-4-87, série A, n. 118 , pp. 22, \$ 64).

A delonga do procedimento incrementou as despesas da requerente nos tribunais italianos, e pode ter contribuído para outros danos. É preciso, pois, levá-Jo em consideração.

A requerente provou, por outro lado, am prejuizo moral indenizável: ela viveu num incerteza e numa ansiedade prolongadas quanto ao resultado e às repercussões do processo.

Estes diversos aspectos não se prestam, in casu, a um cálculo preciso.

Apreciando-os em conjunto e, como determina o art. 50, por eqüidade, a Corte concede à requerente uma indenização no valor de oito milhões de liras.

Por tal motivo, a Corte, à unanimidade,

1. Declara que houve violação ao art. $6^{\circ}: 1$;

2. Declara que o Estado demandado deve pagar à requerente oito milhões de liras a título de satisfação equânime;

3. Rejeita o pedido de indenização acima da condenação ora fixada"

Note-se que, mais recentemente, vários ordenamentos jurídicos salvaguardam nos respectivos textos constitucionais o direito ao processo sem dilações inclevidas.

A Constituição espanhola, de 29 de dezembro de 1978, dispõe, no alt. 24.2, que: "Todos têm direito ao juiz ordinário previantente determinado por lei, à defesa è à assistência de advogado, a ser informado da acusação contra si deduzida, a um processo público sem dilações indevidas e com todas as garantias..."

Como adverte Gimeno Sendra, o termo processo, desse dispositivo constitucional, deve ser entendido como sinônimo de procedimento judicial, e, portanto, as dilações indevidas devem ser afastadas de qualquer gênero de procedimento de natureza penal ou civil, incluídos aqueles de jurisdição voluntária. ${ }^{22}$

É certo também que a "razoabilidade" em tela carece de limites precisos. Trata-se - como entende Placido Fernandez-Viagas Bartolome de uma noção "de

22. Constitución y' proceso, cit., pp. 139. Nicolò Trocker (Pocesso civile e costituzione - problemi di diritno tedesco e italiano, Milano, Giuffè, 1974, pp. 257-8) destaca a impontância da celeridado também nos procedimentos de cunho administrativo. V., sobre a incidencia do due process of law no procedimento adminislrativo brasileiro, Odete Medauar, A processualidade no direimo administrativo, Sũo Paulo, Ed. RT, 1993, pp. 79 ss., não aludindo, contudo, à garantia de julgamento sem atrasos indevidos. 
índole valorativa, portanto, notoriamente imprecisa, que depende das circunstâncias do caso. Ese es precisamente su sentido, desde luego, pero para su adecuada utilización sería necesario el establecimiento previo de un marco o contexto que impida la total discrecionalidad en la materia y, en consecuencia, la inseguridad..." 23

O Tribunal Constitucional da Espanha, em famoso julgamento de janeiro de 1985, deixou assentado que: "O art. 24.2 não constitucionalizon o direito aos prazos, na verdade, constitucionalizou, configurado como um direito fundamental, o direito de toda pessoa a que sua causa seja resolvida dentro de um tempo razó́vel... Este conceito (o do processo sem dilações indevidas, ou em um tempo razoável) é indeterminado ou aberto, que deve ser dotado de um contelido concreto em cada caso, atendendo a critérios objetivos congruentes com seu enunciado genérico, como já ficou deliberado na precedente sentença de 14 de março de 1984" 24

Nessa mesma trilha, a novel revisão do Código de Processo Civil português prevê expressamente, no art. 2-1, o direito a um processo despido de inoportunas procrastinações: "A proteç̧ão jurídica através dos tribunais implica o direito de obter, em prazo razoável, uma decisão judicial que aprecie, com força de caso julgado, a pretensão regularmente deduzida em juizo, bem como a possibilidade de a fazer executar"

Anota, a esse respeito, José Lebre de Freitas que a legislação processual de Portugal assinala um importante passo ao consagrar o direito "a obter, em prazo razoável, uma decisão de mérito e a respectiva execução" 25 Esse postulado fundamental, na verdade, consubstancia-se em uma "derivação do direito de acesso aos tribunais, que a demora desrazóivel dos processos judiciais viola, constituindo uma actuação inconstitucional. A nova lei de processo civil pode (e deve) contribuir. para que esta violação, hoje contínua, deixe de se verificar" 26

Ainda é deste processualista lusitano a informação de que "a duração dos processos judiciais nos tribunais portugueses ultrapassa frequentemente o prazo razoável. Está, porém, hoje geralmente espalhada a compreensão da necessidade de o respeitar" 27

No sistema da common law, de modo assemelhado, a doutrina e a jurisprudência se esforçam para traçar os pressupostos de um processo sem dilações injustificadas.

23. El derecho a un proceso sin dilaciones indebidas, Madrid, Civitas, 1994, |p). 46.

24. Cf, ainda, Fernandez-Viagas Bartolome, El derector a un proceson sin dilaciones indebidas, cil., p). $43-4$.

25. Revisão do processo civil, in Revista da Ordem dos Adrogados, Lisboa, 55(1995): 427.

26. Cf., também, José Lebre de Freitas, Em tommo da revisão do direito processualal civil, in Revista da Ordem dos Adrogados, Lisboa, 5.5(1995): 15.

27. Introduşäo ao processo civil, cit., pp. 113; com a adventência de que: "A progressiva raloraşäo da celeridade processual näo deve, porém, levar a subaltermizan; como por vezes entre nós se verifica. a

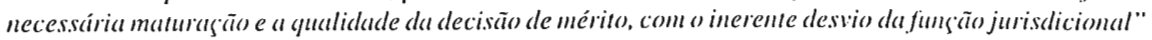


Sem embargo dos litígios conhecerem, em princípio, uma solução mais expedita no âmbito do Direito Americano, é constante a preocupação dos juristas com o problema da intempestividade da tutela jurisdicional. ${ }^{2 x}$

Fruto de minudente pesquisa, a American Bar Association publicou, cm época relativamente recente, o tempo tolerável de duração dos processos nos tribunais ordinários da Justiça norte-americana, a saber:

a) causas cíveis:

a. 1) casos cíveis en geral: $90 \%$ destes devem ser iniciados, processados e concluídos dentro de doze meses; sendo que os $10 \%$ restantes, em decorrência de circunstâncias excepcionais, dentro de 24 meses;

a.2) casos cíveis sumários: processados perante juizados de pequenas causas ("small clains"), devendo ser finalizados em trinta dias;

a.3) "relaçôes domésticas": $90 \%$ destas pendências devem ser iniciadas e julgadas ou encerradas de outro modo no prazo de trinta dias; $98 \%$ dentro de seis meses e $100 \%$ em um ano.

b) causas criminais:

b. l) crimes graves ("felony"): $90 \%$ dos respeclivos processos devem ser extintos no prazo de 120 dias, a contar da data do lato; $98 \% \mathrm{~cm} 180$ dias e $100 \%$, no máximo, em um ano;

b.2) crimes menos graves e contravenções ("misdemeanor"): $90 \%$ dos processos devem ser concluídos em trinta dias e 100\% no prazo máximo de noventa dias;

b.3) delitos praticados por menores ("juvenile"): em caso de prisão do acusado, a solução da questão não pode ultrapassar 24 horas; caso contıário, o julgamento deve ocorrer dentro de trinta dias ${ }^{20}$

É evidente que tais parâmetros variam de modo considerável entre as diversas e complexas espécies de jurisdição do ordenamento norte-americano. Todavia, seja qual for a natureza da causa, é cerlo que o tribunal competente sempre se norteia pelo postulado da celeridade processual ${ }^{30}$

Na verdade, a denominada "speedy trial clause" (cláusula do julgamento rípido) é expressamente contemplada pela 6 "Emenda da Constituição dos EUA.

E, diante desse relevante aspecto, a Suprema Corte americana considera, por exemplo, tempo injustificado aquele decorrente da pendência prolongada de acusação contra um indivíduo sem que se denote qualquer esforço para a conclusão do

28. V., a propósito, A. Clark e J. Merryman, Measuring the duration of judicial and administrative proceedings, in Michigan lasv review, 75(1976):89 ss..

29. Cf. ABA Standards Relating to Court Dela!n Reduction, referido por Bryanı G. Garth, Delay and settlement in civil litigation: noles loward a comparative and sociological perspective, in Studi in onore di Villorio Demti, v. 2, Paılova, Cedam, 1994, pp. 163-5.

30. V. Oscar G. Chase, Civil litigation in Italy and the United States, in The american journal of comparative law, 36(1988): 51 ss.. 
caso: "When the Government's negligence thus causes delay six times as long as that generally sufficient to trigger judicial review..." 31

É bem verdade que a própria Suprema Corte, ao examinar o caso Barker v. Wingo, reconheceu que "o direito a um julgamento rápido ("right to speedy trial") tem um conceito muito vago quando confrontado con outras garantias processuais. É, por exeniplo, impossivel determinar com precisão em quais ocasiões tal direito vem vulnerado..." 32

O ordenamento legal do Canadá também centra essá questão dentre aquelas que merecem particular atenção.

$\mathrm{O}$ art. 11, b, da Carta Canadense dos Direitos e Liberdades, de 1982, reza que: "Toda pessoa demandada tem o direito de ser julgada dentro de um prazo razoável"

Para a doutrina daquela nação, o direito à rápida prestação jurisdicional deve ser aferido a partir do exame: $a$ ) da identificação do interesse que esse direito visa proteger; $b$ ) da determinação dos beneficiários do direito e da relevância da demora; $c$ ) dos vários fatores que devem ser considerados para se verificar se a demora é injustificada; e $d$ ) dos remédios apropriados para combater a violação a tal direito. ${ }^{3.3}$

Importante precedente da Suprema Corte do Canadá, no julgamento do caso CIP Inc., estabeleceu expressamente que os fatores que devem ser considerados "aux fins de déterminer s'il s'agit d'un délai raisonnable sont: (i) la longueur du délai, (ii) la renonciation au délai, (iii) l'explication du délai, et (iv) le préjudice subi par l'accusé"

Atente-se que nesse mesmo acórdão foi debatida interessante questão sobre a abrangência subjetiva da garantia em tela. Discutiu-se então se a regra do citado art. $11, b$, da Carta Canadense, também se estenderia às pessoas jurídicas.

Respondendo afirmativamente, ficou asseverado que: "a expressão tout inculpé - (toda pessoa demandada) - compreende as pessoas morais, de sorte que estas podem se prevalecer da proteção do art. II, b, da Carta. A recorrente tem legítimo interesse en que sua pretensão seja julgada dentro de um prazo razoável. O direito a um processo equânime é fundamental em nosso sistema de contraditório e inclusive consagrado na Constituição. Esta proteção deve incluir todos os litigantes. O interesse social que também fica protegido pelo art. II, b, estende-se às: pessoas morais quando estiverem demandando. Qualquer outra conclusão significa que o sistema apresentaria menor preocupação quando a pessoa juridica fosse parte em um processo judicial, e

31. Cf. Marc Gilbert Doggett v. United States, relatado, em 24-06-92, pelo Juiz Souter, cf. tradução livre: "Quando a negligência da autoridade causa demora seis vezes maiordo que o normal, já é sụficiente para admitir o recurso extraordinário..."

32. In Fernandez-Viagas Bartolome, El derecho a.un proceso sin dilaciones indebidas, cit., pp. 49.

33. Cf. André Morel, Certain guarantees of criminal procedure, in The Canadian Charter of Rights and Freedoms, $2^{3}$ ed., Toronto; Carswell, 1989, pp. 499. V., ainda, Michael Allan Code, Trial within a reasomable time, Toronto, Carswell, 1992, pp. 15 ss.. 
que, ainda, a qualidade de um litigante seria determinante para ter ou não um tratamento 'equânime' e 'justo'", 34

E, em âmbito supranacional, o art. $8^{\circ}, 1$, da Convenção Americana sobre Direitos Humanos, assinada em San José, Costa Rica, em 22 de novembro de 1969, preceitua, verbis: "Toda pessoa tem direito de ser ouvida com as devidas garantias e dentro de um prazo razoável por um juiz ou tribunal competente, independente e imparcial, instituído por lei anterior, na defesa de qualquer acusação penal contra ele formulada, ou para a determinação de seus direitos e obrigações de ordem civil, trabalhista, fiscal ou de qualquer outra natureza..."

Constitui, pois, tarefa dos juristas dos países que aderiram a esse tratado a interpretação da garantia que assegura a todo cidadão o direito de ser julgado dentro de un prazo razoável. ${ }^{35}$

3. Critério da razoabilidade.

3.1. Tempo da investigação criminal

Aduza-se que o denominado Pacto de San José dispôs ainda, no art. $8^{\circ}$ 2 , a regra de que a investigação preparatória do processo penal deve ser ultimada num prazo razoável.

Enquanto alguns sistemas processuais estabelecem um lapso fixo para o desenvolvimento da fase investigatória da persecutio criminis s. $^{36}$, muitos outros, como, pp. ex., o da Alemanha, França e Espanha, não se preocupam em limitar o tempo da atividade pré-processual ("prazos abertos").

Seja como for, a urgência da conclusão da investigação criminal justificase na necessidade inafastável de preservação da prova. Aliás, essa circunstância é, no mínimo, muito curiosa, visto que, após o recebimento da denúncia, a "pressa" que norteia o inquérito diminui de intensidade durante as sucessivas fases da ação penal. ${ }^{37}$

Como se colhe de acórdão proferido pela Suprema Corte do Canadá e no qual ficou reconhecido o direito do acusado a produzir prova sem delongas:

34. Acórdão de 27-6-92, assim ementado: "Droil constitutiomnel - Charre des droits - Procès. danss un délai raisomnable - En raison du manque d'installationss nécessaires, 19 mois se somt éconilés avant que l'accusé ne subisse son procès - Une persomne morale peut-elle invoguer le droit d'être jugé dans un délai raisomnable? Dans l'affirmative, le délai en l'espèce est-il déraisonnable? Charte canadienne des droits et libertés, art. II, b"

35. V., de modo genérico, acerca das garantias processuais na América Latina, Héctor Fix-Zamudio, Constitución y proceso civil en Lainoamérica, México, UNAM-IIJ, 1974, pp. 14 ss..

36. Cf., v. g., Dec.-lei 78, de 17-02-87, de Portugal, que delimila em 6 meses o tempo máximo da investigação criminal; arts. $5.53 \mathrm{c} / \mathrm{c} .405$ e 407 do CPP italiano, que lixam em 4 meses este prazo. Tais ordenamentos, no entanto, ressalvam a possibilidade de dilatação do tempo previsto em situaçōes excepcionais: cf. Fauzi Hassan Chouke, Garantias constinucionais na investigagăo criminal, São Paulo, EJ. RT, 1995, pp. 132-3.

37. V., ainda que sobre diferente situação, o enunciado da Stimula $2 /$ do STJ: "Promunciado (" réll. fica superada a alegação do constrangimento ilegal da prisão por excesso de prazo na instrușäo" 
"Independentemente da natureza da infração, subsiste o interesse para o acusado em obter uma prova disponível e confiável. O presente litígio não é complicado e alguns dos adiamentos não foram causados pela defesa. A explicação da demora em tela indica o ministério público como responsável...".3.

O direito brasileiro também não conhece um obstáculo temporal para a investigação criminal. "Há, por certo, a previsão do art. 10 do $C P P$, onde se deternina que o inquérito será 'concluído' em dez dias caso o indiciado estiver preso, ou trinta, se solto, mas não é disto que se trata. Muito embora tenha o legislador procurado delimitar temporalmente o trâmite da investigação, não soube fazê-lo, criando un artigo superficialmente rigoroso, mas praticamente inoperante, além de tecnicamente imperfeito. Imperfeito enquanto técnica (e sistema) porque despreza a atividade valorativa do titular da ação penal, que dará a última palavra sobre quando o feito está verdadeiramente concluído e apto para ensejar a propositura da ação penal ou o arquivamento da investigação. Assim é que, mesmo na hipótese mais drástica (indiciado preso), onde o prazo é menor, nem por isto necessariamente dá-se por concluída a investigação no decêndio. Certo é que, nesses casos, não pode o indiciado continuar sofrendo uma constrição à tiberdade e, se não oferecida a inicial acusatória dentro do prazo aludido, deverá ser posto solto. Mas isto em hipótese alguma significa que a investigação será encerrada ao final do termo mencionado, ao contrário, ela se estenderá para que o legitimado ativo possa formar sua convição" "3"

Criticando a "frouxidão" do modelo brasileiro, entende Fauzi Chouke que a ausência de barreira cronológica para o encerramento da investigação criminal fomenta a dilação temporal do processo penal.

Daí, porque, à luz da determinação supra aludida da Convenção Americana sobre Direitos Humanos, pode-se sugerir que o Brasil "filia-se à idéia da razoabilidade para a conclusão da investigação, nuito embora seja prematuro o amparo jurisprudencial e doutrinário, tendo em vista a recém entrada em vigor daquele diploma" 40

\subsection{Tempo da prisão provisória}

É bem de ver, por outro lado, que o art. $7^{\circ} 5$, do Pacto de San José, reproduzindo o enunciado do $5^{\circ}, 3$, da Convenção Européia para Salvaguarda dos Direitos do Homem e das Liberdades Fundamentais, também contempla, sob a ótica do processo penal, o direito de qualquer cidadão "ser julgado dentio de un prazo razoável ou ser colocado em liberdade, sem prejuízo da continuação do processo" aduzindo que "sua liberdade poderá estar condicionada a garantias que assegurem seu comparecimento em juízo"

Discorrendo sobre o tempo máximo da prisão provisória, preconiza Daniel Domínguez Henaín que o limite do "plazo razonable para ser juzgado del que

38. No julgamento, já referido, de CIP Inc., em 27-6-92.

39. Cf. Fauzi Hassan Chouke, Garantas constinucionais na investigasüo criminal, cit., pp. 137-8.

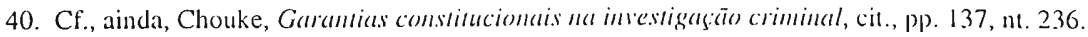


habla el Pacto de San José, superado el cual se debe liberar el detenido, es un tema que ha quedado a la determinación discrecional de los paises signatarios, quienes se comprometieron a respetar los derechos y libertades reconocidos en la Convención (art. $1^{\circ}$ ), y a adoptar, con arreglo a sus procedimientos constitucionales y a las disposiciones de la Convención, las medidas legislativas o de otro carácter que fueren necesarias para hacer efectivos tales derechos y libertades (art. $2^{\circ}$ )"

Esclarece, outrossim, o processualista argentino que, em seu país, a Lei 24.390, de 22 de novembro de 1994, regulamentou a regra do art. $7^{\circ} 5$, da Convenção Americana, estabelecendo três critérios que permitem a dilação do prazo reputado razoável para que o acusado seja julgado ou colocado em liberdade. A prisão preventiva, consoante o art. $1^{\circ}$ da citada lei, não deverá ser superior a 2 anos. Todavia, esse prazo razoável poderá ser prorrogado nas seguintes hipóteses: a) delesa manifestamente dilatória; $b$ ) evidente complexidade da causa; e $c$ ) condenação ainda sujeita a recurso. ${ }^{41}$

Saliente-se que, na órbita dos países membros da Comunidade Comum, à luz do supra citado art. $5^{\circ}, 3$, da Convenção Européia, a questão do tempo de duração da prisão recebeu especial atenção da Corte de Estrasburgo. Em dois importantes julgamentos praticamente idênticos, proferidos nos casos Neumeister e Wemhoff, o critério da razoabilidade foi detidamente examinado.

No primeiro deles, contra o Estado austríaco, ficou assinalado que: " $A$ Corte, para facilitar o exame, entende que o caso deve ser examinado seguindo sete 'critérios' 'fatores' ou 'elententos' a saber: I A efetiva duração da detenção. A Corte não deseja dizer que tenha de fixar um 'limite temporal absoluto' de duração da prisão. Tampouco se trata de mensurar esta duração em si mesma, mas, sim, de utilizála como un dos critérios que permitan determinar o seu caráter razóvel. II - A duração da prisão preventiva em relação à natureza da infração, extensão da pena prevista e que deve ser aplicada em caso de condenação e, ainda, sistema legal de cumprimento da pena no caso concreto. A esse respeito, a Corte adverte que a duração da prisão preventiva pode variar consoante a natureza da infração, a extensão da pena prevista $e$ da pena que seria aplicada ao caso. Não-obstante, para apreciar a relação entre a pena e a duração da prisão preventiva, segundo a Corte, deve ter-se en conta a presunção de inocência estabelecida no art. 6.2 da Convenção. Se a duração da detenção se aproxima excessivamente à da pena aplicável, não estaria sendo integralmente respeitado o princípio da presunção de inocência. III Os efeitos materiais, morais e de outra natureza que a detenção produz sobre o detido. IV A conduta do acusado: a) Contribuiu ele para atrasar ou acelerar a instrução e os debates? b) Se atrasou o procedinento como resultante da apresentação de requerimentos de liberdade provisória, de apelações e de outros recursos? c) Pediu a liberdade mediante fiança ou ofereceu outras garantias para assegurar seu comparecimento em juízo? V - As dificuldades da instrução do caso (a complexidade

41. V., a propósito, Daniel Domínguez Henaín, Ley 24.390 - prisión preventiva plazo máximo cómputo del encarcel (umiento caurelar, Rosario, Juris, 1996, pp. 7 ss.. 
dos fatos ou do número de tetsemunhas e acusados, necessidade de colher provas no estrangeiro, etc.). VI O modo pelo qual se realizou a instrução: a) o sistenia que rege a instrução; b) a direção da instrução pelas autoridades (o cuidado e a maneira de condução da instrução. VII A atuação das autoridades judiciais: a) o exame dos pleitos de liberdade durante a instrução; b) a sentença do caso", 42

Malgrado esse elogiável esforço, esclarece Fernandez-Viagas Bartolome que o juiz Terje Wold, na declaração de voto que proferiu no julgamento do caso Wemhoff, não deixou de advertir que: "Es ciertanente útil que la Comisión hay'a tratado de establecer una lista de siete criterios que pueden ser tomados en consideración... Yo estoy, sin embargo, de acuerdo con la mayoría en estimar que el Tribunal no puede recomendar esta manera de proceder. Por una parte, la lista nunca podrá ser completa..." 43

Recorrendo aos aludidos critérios, mais recentemente a Corte Européia, diante da complexidade do processo, não reconheceu desarrazoado o lapso de quatro anos de prisão provisória do acusado, e, portanto, julgou improcedente o pedido formulado no caso W. v. Suisse (26-1-93). ${ }^{\text {th }}$

Entre nós, cuidando das modalidades de prisão provisória é seu prazo de duração 4 Roberto Delmanto Júnior explica que "há países que não se contentaram com o preceito da Convenção Americana, dado a sua elasticidade e subjetivismo, preferindo ir além, prescrevendo em suas constituições que a lei ordinária necessariamente estipulará o prazo para a prisão provisória, como se verifica em Portugal, na Itália e na Espanha... Sem dúvida, o fato de existirem instrumentos internacionais que venham a prever esse direito não impede que os Estados subscritores legislem de maneira mais especifica, prescrevendo prazos em montante proporcional e razoável (para não se feriro analisado conceito de "due process of law"), não deixando ao critério exclusivo dos tribunais a verificação se os órgãos da persecução penal estão agindo de forma diligente ou não, utilizando-se de uma série de critérios subjetivos, como fazem, por exemplo, o Canadá e os EUA"

Trata-se, como se observa, de opção de política legislativa, sendo, todavia, aconselhável que, à luz da razoabilidade ditada pela Convenção Americana, o legislador pátrio discipline, de torma objetiva e norteado pela excepcionalidade da prisão cautelar, o respectivo prazo de duração. ${ }^{46}$

42. In Fernandez-Viagas Bartolome, El derecho a un proceso sin dilaciones indebidas, cit., p|). 79-80;

43. El derecho a un proceso sin dilaciones indebidas, cit., pp. 80.

44. Cf. Jean-Pierre Marguénaud, La Cour européenne des droits de l'homme, cit., p|). I(04. V., também, Faúndez Ledesma, El derecho a un juicio justo, cit., pp. 158, informando que, excepcionalmente, a Corte Européia estimou razoável, dadas as circunstâncias do caso, um período de 8 anos (Hacise v. Alemarihar12-7-77); e também aceitou como razoável um lapso de aproximadamente 5 anos (Buch/holz v: Alemam/ha $-6-5-81)$.

45. Rio de Janeiro, Renovar, 1998, pp. 27I ess.

46. Cf. Delmanto, As modalidades de prisũo provisória e seu prazo de durașino, cit., pp. 274. 
Daí porque, com razão, Lauria Tucci apontou a irrazoabilidade "( $e$ conseqüentemente, a inconstitucionalidade, por afronta ao devido processo penal), do disposto no $\$ 3^{\circ}$ do art. $2^{\circ}$ da Lei n. 8.072, de 25 de julho de 1990" (Lei dos crimes hediondos), que ampliou o prazo da prisão temporária para trinta dias, prorrogável por mais $30 .{ }^{47}$

Note-se, por fïm, que, diferentemente, a prisão civil, no ordenamento brasileiro, tem tempo máximo pré-fixado (trinta a noventa dias: dívida alimentar; ou 1 ano: depositário infiel), a teor do disposto nos arts. $5^{\circ}$, LXVII, da Constituição Federal, $733, \S 1^{\circ}$, e $902, \S 1^{\circ}$, do Código de Processo Civil.

3. Recepção da garantia pelo Direito brasileiro.

A nossa atual Constituição da República inseriu, no inc. LIV do art. $5^{\circ}$. uma cláusula geral, assegurando, explicitamente, a garantia do due process of law: "Ninguém será privado da liberdade ou de seus bens sem o devido processo legal"

E, ainda, para que ficasse estreme de dúvidas, além dessa preceituação genérica, já suficiente para alcançar o fïm por ela colimado, previu, em vários incisos do citado art. $5^{\circ}$, incorrendo em manifesta redundância (porém louvável...), inúmeros corolários da gaiantia constitucional do devido processo legal.

Nada dispôs, contudo, acerca do direito à tutela jurisdicional dentro de um prazo razoável...

A teor do $\$ 2^{\circ}$ do mesmo art. $5^{\circ}$ : "Os direitos e garantias expressos nesta Constituição não excluem outros decorrentes do regime e princípios por ela adotados, ou dos tratados internacionais em que a República Federativa do Brasil seja parte"

Assim, diferentemente, por exemplo, da orientação perfilhada pelo direito alemão, no sentido de que "fora da Constituição não existe norma fundamental alguma" ("Aus der Grundgesetz keine Grundnorm ist") ${ }^{4 \times}$ o Brasil admite expressamente a vigência de texto legal supranacional, desde que tenha aderido ao mesmo e que não apresente antinomia com o Direito interno.

Oportuno, nesse passo, lembrar que o nosso País é signatário do já mencionado Pacto de San José de Costa Rica, que adquiriu eficácia internacional, em 18 de julho de 1978. O Congresso Nacional, posteriormente, mediante o Decreto 27, de 26 de maio de 1992, aprovou o seu texto, sendo que o nosso Governo, em 25 de setembro do mesmo ano, depositou a respectiva Carta de Adesão à apontada Convenção.

Com a ulterior publicação do Decreto 678 (9-11-92), o Pacto de San José foi promulgado e, finalmente, incorporado ao Ordenamento Jurídico brasileiro.

Como o rol das formalidades legais foi rigorosamente cumprido, deduz

47. Direitos e garantias individuais mo processo penal brasileiro, cit., pp. 290 , nt. 10.

48. V., a respeito, F. Stern, Kommentar zur Bomner Grundgesetz, Hamburg, 1982, pp. 241. 
Luiz Flávio Gomes ser evidente que, no Brasil, todos devem obediência aos ditames da Convenção Americana sobre Direitos Humanos. ${ }^{49}$

Ficou, outrossim, assentado, no importante voto proferido pelo juiz Antonio Carlos Malheiros, no julgamento do habeas corpus 637.569-3, da $8^{\mathrm{a}}$ Câmara do $1^{\circ}$ Tribunal de Alçada Civil de São Paulo, que se pode concluir, "com razoável tranqüilidade, que os princípios emanados nos tratados internacionais, a que o Brasil tenha ratificado, equivalem-se às próprias normas constitucionais". ${ }^{51}$

Desse modo, a despeito da garantia do devido processo legal pressupor; como já ressaltado, o rápido desfecho do litígio ou da persecutio criminis, encontra aplicação, em nosso sistema jurídico, dada a cvidente compatibilidade de regramentos, o disposto no art. $8^{\circ}, 1$, do referido Pacto: "Toda pessoa tem direito de ser ouvida com as devidas garantias e dentro de um prazo razoável..."

4. Devido processo legal e seus corolários (o tempo justo).

A partir da concepção formulada por Häberle, de um status activıs processualis, passou-se a reconhecer nos direitos fundamentais um "prisma processual", cuja realização prática é condição de efetividade da respectiva proteção constitucional à tutela jurisdicional..$^{51}$

O processo, como é notório, presta-se como instrumento de exercício do direito à jurisdição, sendo que seu desenrolar, com estrita observância dos regramentos ínsitos ao denominado due process of law, importa na possibilidade de inarredável tutela de direito subjetivo material objeto de reconhecimento, satisfação ou assecuração em juízo. Assim também, sob a perspectiva da posição do réu, o mesmo ocorre com a tutela jurisdicional de seu respectivo direito, caso tenha ele razão.

Não basta, pois, que se assegure o acesso aos tribunais, e, conseqüentemente, o direito ao processo. Delineia-se inafastável, também, a absoluta regularidade deste (direito no processo), com a verificação efetiva de todas as garantias resguardadas ao consumidor da Justiça, em um breve prazo de tempo, isto é, dentro de um tempo justo, para a consecução do escopo que lhe é reservado.

Em síntese, a garantia constitucional do devido processo legal deve ser uma realidade durante as múltiplas etapas do processo judicial, de sorte que ninguém seja privado de seus direitos, a não ser que no procedimento em que este se materializa sejam constatadas todas as formalidades e exigências em lei previstas. ${ }^{52}$

49. Direito de apelar em liberdade, 2a ed., São Paulo, Ed. RT, 1996, pp. 83-4. Ressalvam-se, contudo, aquelas disposiçōes que eventualmente conflitem com preceitos de nossa Constituição Federal.

50. V., acerca da hierarquia legal dos pactos internacionais, o profundo estudo de Flívia Piovesan, Direitos humanos e o direito constitucional internacional, São Paulo, Max Limonad, 1996.

51. Verfassung als äffentlicher Prozess, Berlim, 1978, pp. 59 e ss. V., a respeito, Robert Alexy, Terria de los derechos fundamentales, tr. cast. Ernesto Garzón Valdés, Madrid, CEC. 1997, p). 463 e ss.

52. Cf. Tucci e Tucci, Constiluigão de 1988 e processos, São Paulo, Saraiva, 1989, pp. 17, com referência, é claro, ao duc process of law em senso processual. V., ainda, o original posicionamento de Horácio D. Rosatti, El derecho a la jurisdicción antes del proceso, Buenos Aires, Depalma, 1984, pp. 31 e ss. 
Desdobram-se estas nas garantias: $a$ ) de acesso à Justiça; $b$ ) do juiz natural ou preconstituído; c) de tratamento paritário dos sujeitos parciais do processo; d) da plenitude de defesa, com todos os meios e recursos a ela inerentes; e) da publicidade dos atos processuais e da motivação das decisões jurisdicionais; e f) da tutela jurisdicional dentro de um lapso temporal razoável.

Conclui-se, portanto, que, também em nosso País, o direito ao processo sem dilações indevidas, como corolário do devido processo legal, vem expressamente assegurado ao membro da comunhão social por norma de aplicação imediata (art. $5^{\circ}, \S$ $\left.1^{\circ} \mathrm{CF}\right)$.

São Paulo, novembro de 2001.

Bibliografia.

Albacar Lopez, José Luis. La durata e il costo del processo nell'ordinamento spagnolo, in Rivista trimestrale di diritto e procedura civile, tr. it. Gigliola Funaro, 1983.

Alexy, Robert. Teoria de los derechos fundamentales, tr. cast. Emesto Garzón Valdés, Madrid, CEC, 1997.

Anselmo Vaz, Teresa Sapiro. Novas tendências do processo civil no âmbito do processo declarativo comum (alguns aspectos), in Revista da Ordem dos Advogados, Lisboa, 55, 1995.

Barbosa Moreira, José Carlos. Notas sobre o problema da "efetividade" do processo, in Ajuris, 29, 1983.

—. Tendências contemporâneas do direito processual civil, in Temas de direito processual, 3ª s., São Paulo, Saraiva, 1984.

Bielsa, Rafael e Graña, Eduardo. El tiempo y el proceso, in Revista del Colegio de Abogados de La Plata, La Plata, 55, 1994.

Carnelutti, Francesco. Diritto e processo, Napoli, Morano, 1958.

Carrió, Alejandro D.. Garantias constitucionales en el proceso penal, Buenos Aires, Hammurabi, 1984.

Chase, Oscar G.. Civil litigation in Italy and the United States, in The american journal of comparative law, 36, 1988.

Chouke, Fauzi Hassan. Garantias constitucionais na investigação criminal, São Paulo, Ed. RT, 1995.

Clark, A. e Merryman, J.. Measuring the duration of judicial and administrative proceedings, in Michigan law review, 75, 1976.

Code, Michael Allan. Trial within a reasonable time, Toronto, Carswell, 1992. 
Cruz e Tucci, José Rogério. Dano moral decorrente da excessiva duração do processo, in Temas polêmicos de processo civil, São Paulo, Saraiva, 1990.

Garantia da prestação jurisdicional sem dilações indevidas como corolário do devido processo legal, in Devido processo legal e tutela jurisdicional, São Paulo, Ed. RT, 1993.

Delmanto Júnior, Roberto. As modalidades de prisão provisória e seu prazo de duração, Rio de Janeiro, Renovar, 1998.

Dinamarco, Cândido Rangel. A instrumentalidade do processo, $5^{\mathrm{a}}$ ed., São Paulo, Malheiros, 1996.

Domínguez Henaín, Daniel. Ley 24.390 - prisión preventiva plazo máximo cómputo del encarcelamiento cautelar, Rosario, Juris, 1996.

Faúndez Ledesma, Héctor. El derecho a un juicio justo, in Revista de la faculdad de Ciencias Jurídicas y Políticas, Universidad Central de Venezuela, 80, 1991.

Fernandez-Viagas Bartolome, Placido. El derecho a un proceso sin dilaciones indebidas, Madrid, Civitas, 1994.

Fix-Zamudio, Héctor. Constitución y proceso civil en Latinoamérica, México, UNAM-IIJ, 1974.

Freitas, Joșé Lebre de. Em torno da revisão do direito processual civil e Revisão do processo civil, in Revista da Ordem dos Advogados, Lisboa, 55, 1995.

- Introdução ao processo civil conceito e princípios gerais à luz do Código revisto, Coimbra, Coimbra Ed., 1996.

García Arán, Mercedes. La prevaricación judicial, Madrid, Tecnos, 1990.

Garth, Bryant G. .Delay and settlement in civil litigation: notes toward a comparative and sociological perspective, in Studi in onore di Vittorio Denti, v. 2, Padova, Cedam, 1994.

Gimeno Sendra, Vicente, Moreno Catena, Víctor e Cortés Domínguez, Valentín. Derecho procesal proceso perial, Valencia, Tirant Lo Blanch, 1993.

Gimeno Sendra, Vicente. Constitución y proceso, Madrid, Tecnos, 1.988.

Gomes, Luiz Flávio. Direito de apelar em liberdade, $2^{a}$ ed., São Paulo, Ed. RT, 1996.

Grzybek, Patrick. Prozessuale Grundrechte in Europäischen Gemeinshaftsrecht, Baden-Baden, Nomos, 1993.

Häberle, PP.. Verfassung als öffentlicher Prozess, Berlim, 1978.

Marguénaud, Jean-Pierre. La Cour européenne des droits de l'homme, Paris, Dalloz, 1997.

Marinoni, Luiz Guilherme. Tutela antecipatória, julgamento antecipado $e$ execução imediata da sentença, São Paulo, Ed. RT, 1997.

Medauar, Odette. A processualidade no direito administrativo, São Paulo, Ed. RT, 1993. 
Morel, André. Certain guarantees of criminal procedure, in The Canadian Charter of Rights and Freedoms, $2^{a}$ ed., Toronto, Carswell, 1989.

Piovesan, Flávia. Direitos humanos e o direito constitucional internacional, São Paulo, Max Limonad, 1996.

Proto Pisani, Andrea. Appunti sulla tutela di condanna, in Studi in onore di Enrico Tullio Liebman, v. 3, Milano, Giuffrè, 1979.

Rosatti, Horácio D.. El derecho a la jurisdicción antes del proceso, Buenos Aires, Depalma, 1984.

Sanchez-Cruzat, José M. Bandres. El tribunal europeu de los derechos del hombre, Barcelona, Bosch, 1983.

Silva, Ovídio A. Baptista da. Curso de processo civil, v. 1, Porto Alegre, Sérgio Fabris, 1987.

Stern, F.. Konmentar zur Bonner Grundgesetz, Hamburg, 1982.

Tarzia, Giuseppe. Quali riforme pela la giustizia civile?, in Giurisprudenza italiana, 1987, pt. IV.

Tomé Garcia, José Antonio. Protección procesal de los derechos humanos ante los tribunales ordinarios, Madrid, Montecorvo, 1987.

Trocker, Nicolò. Processo civile e costituzione problemi di diritto tedesco e italiano, Milano, Giuffrè, 1974.

Tucci, Rogério Lauria e Cruz e Tucci, José Rogério. Constituição de 1988 e processo, São Paulo, Saraiva, 1989.

Tucci, Rogério Lauria. Direitos e garantias individuais no processo penal brasileiro, São Paulo, Saraiva, 1993.

Yarshell, Flávio Luiz. Tutela jurisdicional e tipicidade, tese de doutoramento (USP), São Paulo, 1997. 